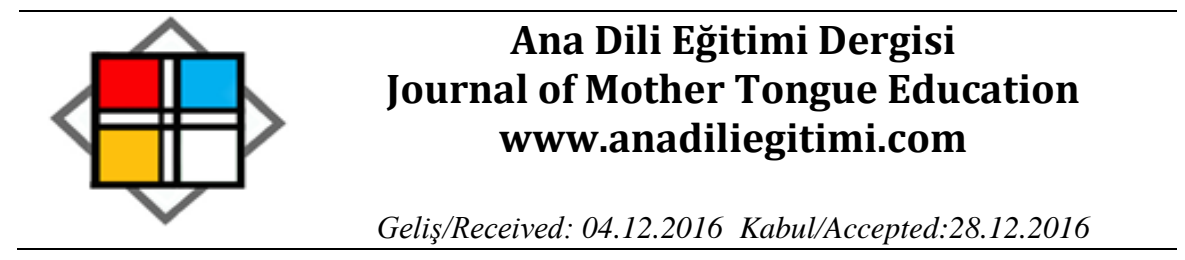

\title{
Kazakistan Cumhuriyetinde Eğitim Sisteminin Tarihî Seyri ve Günümüzdeki Yapısı
}

\author{
ibrahim KAPLANKIRAN*
}

Öz

Bu çalışma, Kazakistan Cumhuriyetindeki eğitim sisteminin başlangıçtan günümüze kadarki tarihî seyrinin incelenmesi için hazırlanmıştır. Kazakistan, uzun yıllar Rus hâkimiyeti altında yaşamış Çarlık Rusya ve Sovyet Rusya- ve Sovyetler Birliğinin dağılmasından sonra 16 Aralık 1991 yılında bağımsızlığını ilan etmiş bir ülkedir. Yaşanan Rus hâkimiyetleri neticesinde de doğrudan veya dolaylı olarak pek çok yönde değişimlere, baskılara ve asimilasyonlara maruz kalmıştır. Özellikle Sovyet Rusya döneminde daha sistemli bir şekilde yürütülmeye başlayan bu politikalar çeşitli yöntem ve stratejilerle Kazak eğitim sisteminde de görülmüş ve tüm halk Sovyetleştirilmeye çalışılmıştır. Bu çalışmada Batı Türklüğü ile dil-kültür ilişkisi bakımından köklü bir geçmişe sahip olan Kazakistan Cumhuriyetindeki eğitim sisteminin temelleri, tarihî gelişimi ve günümüzdeki yapısı ele alınmıştır. Bu incelemenin alanla ilgili yapılacak daha kapsamlı ve farklı araştırmalara katkı sağlayacağı ve Türk Dünyası arasındaki eğitim çalışmalarını daha da ileri götüreceği kanaatindeyiz.

Anahtar Kelimeler: Kazakistan Cumhuriyeti, Kazaklar, Kazak Türkçesi, Eğitim Sistemi, Pedagoji Tarihi

\section{Historical Course of the Education System in Kazakhstan Republic and Its Structure Today}

\begin{abstract}
This study was conducted in order to examine the historical course of the education system in the Kazakhstan Republic from its beginning till today. Kazakhstan, having lived under Russian domination for many years - Tsarist Russia and the Soviet Union - is a country that declared its independence on December $16^{\text {th }}, 1991$ after the disintegration of the Soviet Union. As a result of the Russian dominance, the country was subject to numerous direct or indirect changes, oppression, and assimilation. Those policies which started to be applied more systematically during the Soviet Russia period were witnessed in the Kazakhh education system through various methods and strategies and the entire nation was attempted to be Sovietized. In this paper, the basics of the education system in the Kazakhstan Republic, which has a long-established history in terms of language-culture relation with Western Turkishness and its historical course along with its present structure, were examined. We believe that this search will contribute to more detailed and different future studies in the field and will further the educational studies in the Turkish World.
\end{abstract}

Key Words: The Kazakhstan Republic, Kazakhs, Kazakh Turkish, Education System, History of Pedagogy

\footnotetext{
* Okutman, Ahmet Yesevi Uluslararası Türk-Kazak Üniversitesi, Hazırlık Fakültesi, Türk Dili Bölümü, Türkistan/KAZAKISTAN, kaplankiran86@hotmail.com
} 


\section{Giriş}

“Eğitim, bireyleri sahip oldukları potansiyelleri ölçüsünde farklı boyutlarıyla geliştirmeyi amaçlayan bir süreçtir" (Demir, Doğan, Pınar, 2013: 1082). Toplumların ve ülkelerin yetiştirmek istediği insan profilini belirlemede önemli bir araç olan eğitim bu yönüyle de diğer tüm mekanizmaların ana unsurunu teşkil etmektedir. "Eğitim, çocuğun ailesi ile başlamakta, sosyal çevresi ile sürdürülmekte, okul dönemini içermekte ve çalışma hayatına başlamasıyla mesleğini de kapsayarak bir yaşam boyu devam etmekte olan bir süreçtir" (Shuinshina, 2006: 1). İnsan hayatıyla ilgili doğrudan veya dolaylı olan her şey, eğitimin konusu içerisine girmekte ve insanların, toplumların, milletlerin ve ülkelerin başarılarına etki etmektedir.

“insanın eğitime muhtaç ve eğitilebilir bir canlı olmasından dolayı, eğitim insanlık tarihi kadar eski bir faaliyet alanıdır. İnsan türünün yaşayabilmesi eğitime bağlıdır” (Ergün, 2008: 1). Eğitim, toplumların maddî ve manevî tüm unsurlarını geleceğe sağlıklı bir şekilde taşıyabilecek en önemli etken olup aynı zamanda ülkelerin çıkarları doğrultusunda bekasını da garanti altına alan işlevsel bir yapıdır. Bütün bu unsurları sağlıklı bir şekilde hayata geçirmek ve istenilen başarıyı sağlayabilmek için de tüm eğitim faaliyetlerinin bir sistem, düzen, metot ve plan dâhilinde ele alınması ve her alanda uygulanması gerekmektedir.

Bu nedenle gerek yurt içinde gerekse yurt dışında eğitim çalışmalarının araştırılması ve incelenmesi; insanların, toplumların, milletlerin ve ülkelerin başarılarını arttıracak ve ideal bir eğitim sistemin ortaya konulabilmesine katkılar sağlayacaktır. Bütün bu hassasiyetlerin bilindiği ülkelerde bu konu, sistemli ve düzenli bir şekilde yapılmakta ve yeni arayışlara ortam hazırlanılmaktadır.

Kazakistan'ın uzunca bir süre Rus hâkimiyetinde yaşaması Kazakların millî eğitim sistemlerinin gelişimini olumsuz yönde etkilemiş ve bu durum, ortak kültüre sahip olduğu diğer Türk Cumhuriyetleriyle dil ve kültür birliği bağının zayıflamasına neden olmuştur. Yaşanılan tüm bu olumsuzluklara rağmen Kazak eğitim sistemi içerisinde önemli bilim adamları, edebiyatçılar ve araştırmacılar da yetişmiş ve çalışmalarıyla Kazak eğitiminde önemli çalışmalar yapmışlardır.

Dil ve kültür ilişkisi bakımından aynı ortak değerlere sahip olan Kazakistan ve Türkiye tüm alanlarda işbirliği yapmayı, yakınlaşmayı ve bu çalışmaları sürdürmeyi geçmişten günümüze her zaman bir devlet politikası olarak benimsemiştir. "1990'lı yılların başından itibaren, Türkiye ve Kazakistan Cumhuriyetleri arasında siyasal, sosyal, kültürel, iktisadî ve ticarî alanlarda da işbirliği çalışmaları başlatılmıştır. 01.05.1992 tarihinde, Almatı şehrinde iki ülke arasında eğitim alanında da ilişkilerinin geliştirilmesi ve işbirliğini öngören anlaşmalar yapılmıştır" (Shuinshina, 2006: 8).

Bu noktalardan hareketle Kazakistan Cumhuriyetindeki eğitim sistemini geçmişten günümüze araştırmak ve incelemek her iki ülkenin birbirleriyle yaptığı/yapacağı ortak çalışmaları daha da ileriye götürerek güçlendirecektir. 


\section{Ülkede Eğitimin Dayandığı Temeller ve Eğitim Sisteminin Günümüze Kadarki Tarihî Seyri}

Kazakistan'da eğitim sisteminin temellerinin atılması ve gelişmesi farklı dönemlere ve çalışmalara bakılarak tasnif edilmektedir. Araştırmacılar tarafından çeşitli kriterlerin dikkate alınmasıyla yapılan tasnifler, genelde aynı sınırlar içerisinde yer almaktadır. Ülkedeki eğitim sisteminin tarihi, üç temel döneme dayandırılarak sınıflandırılmaktadır:

1. Dönem: VI-XV Asırlar Arasındaki Temel Dönem;

2. Dönem: XV. Asrın Illk Yarısından XX. Asrın Başına Kadarki Dönem;

3. Dönem: XX. Asrın Başlarından Günümüze Kadar Olan Dönem.

Yapılan bu tasnifi daha da ayrıntılandıracak olursak 1. dönemde Orhun Yenisey Yazıtlarını görmekteyiz. Bilge Kağan için dikilen yazıtlarda; Türk halkının kendi kağanlarından ve öz yurtlarından ayrımamaları gerektiği yazıımıştır. "Bölüneni kurt kapar, eğer beraber yaşarsanız, birlik içerisinde olursanız, kaygısız mutlu bir ömür sürersiniz" sözüyle pedagojik düşüncenin temellerinin atıldığı açıkça gösterilmiştir (Bayjanova, 2008: 19). Bu dönemde zikredilen diğer isimler; bozkırın ulu düşünürü Kopuzcu Dede Korkut ve psikolojik ve pedagojik fikirleri ve çalışmalarıyla bilinen Ebu Nasır El Farabi'dir.

Kazakistan'da bilimsel çalışmaların başlaması ve gelişmesi çok eski zamanlara dayanmaktadır. Kazakistan'da -özellikle yerleşik bölgelerde- orta çağlardan daha önceki devirlerdeki 7. ve 8. yüzyıllarda pek çok okul, medrese ve dinî bilgiler veren eğitim kurumlarının çalışmalar yaptığı tarihî belgelerden anlaşıımaktadır. Önceden İsfidjab, Taraz, Sayram, Türkistan, Otırar vb. şehirlerde birçok medrese bulunduğu ve bunların genel sayısının 84'e ulaştığı bilinmektedir (Kurmanalina, Mukanova, Galimova ve Illyasova, 2010: 68). Bu yerleşim yerlerindeki okullarda Tatar, Başkurt vb. mollalar öğretmenlik yapmışlardır. Halktan toplanan paralarla sürdürülen eğitimde çocuklar, kış ve sonbahar aylarında 4 yıl süreyle öğrenim görmüşlerdir. Öğrenciler 7 yaşından itibaren okula başlamış ve bu öğrencilere her eğitim-öğretim döneminin sonunda belirli sınavlar yapılmıştır. Ayrıca sınav sonuçlarına göre öğrencilere resmî birer belge de verilmiştir. Medreselerde verilen eğitim sadece Arap ve İslam geleneklerinin etkisinde olmamış, aynı zamanda evrensel düzeyde hizmet de verilmiştir. Bu eğitim sisteminde; hukuk, tarih, mantık, felsefe, matematik, astronomi, tıp vb. dersler okutulmuş olup ayrıca medreselerin yanında oldukça donanımlı kütüphaneler de kurulmuştur (Kurmanalina, Mukanova, Galimova ve illyasova, 2010: 68).

Pedagojik düşüncelerin gelişmesinin 2. dönemi; XV. asırların birinci yarısındaki Kazak Hanlığının ortaya çıkmasıyla olmuştur. Bu dönemden XX. asrın başlarına kadar devam eden dönemin özelliği; eğitim ve hayat ile ilgili düşünceleri ele alan aydınların, şairlerin, destancıların ve eserlerinin olmasıdır. Akpambet, Şalkiyiz, Süyinbay gibi halk ozanları ve destancıları ile Şokan Valihanov, Ibıray Altınsarin, Abay Kunanbayev, Şakerim Kudayberdiulı, Jambıl Jabayev gibi önemli isimler, eserlerinde eğitimin bütün hususlarıyla ilgili düşüncelerini bu dönemde dile getirmişlerdir (Bayjanova, 2008: 19). 
XV. asrın ilk yarısından XX. asrın başına kadarki bu dönemde Kazaklar, her konuda olduğu gibi eğitimde de pek çok sıkıntılı olayla karşılaşmıştır. "1552 senesinde Kazan’ı istila eden Çarlık Rusyası, bu tarihten hemen sonra Kazak bozkırlarına akın etti ve sömürgecilik faaliyetlerine başladı" (Boranbayeva, 2004: 21). Çarlık Rusya'nın, 1552 yılında Kazan'ı işgal etmesiyle birlikte Kazakistan'da Rus hâkimiyeti resmen başlamış ve bu tarihten itibaren zorlu süreçlerin yaşanacağı bir döneme girilmiştir. Bu süreç, Rus Çarı 1. Nikola'nın 22 Haziran 1854 yılında çıkarmış olduğu bir fermanla yeni ve farklı bir alana taşınmış ve tüm dünyaya resmen ilan edilmiştir. Farklı bir alana taşınan ve tüm dünyaya ilan edilen bu fermanla, Kazak coğrafyasının tamamen Rus hâkimiyeti altına girdiğini ve Kazakların bundan sonra bütünüyle Ruslara tabi olduğunu görüyoruz (Boranbayeva, 2004: 21).

Çarlık Rusya'nın 150 yıla uzanan sömürgeci siyaseti, halkın egemenlik yolundaki mücadelesine büyük zarar vermiş; ama aynı zamanda bu durum, Batı ile Doğunun irtibat kurmasını sağlamıştır. Örneğin, 1761 yılında Çarlık Rusya, Doğu Kazakistan'daki Zmeynogorski'de yer alan kurşun-çinko maden bölgesindeki maden işçilerinin çocuklarına tahsis edilen bir okul açmıştır. 1786 yılında Ombı şehrinde 'Aziyalıktar Mektebi'nin temelleri atılmış ve daha sonra 1789 yılında Orınbor şehrinde olmak üzere buna benzer okullar ülkenin değişik yerlerinde açılmıştır (Kurmanalina, Mukanova, Galimova ve ilyasova, 2010: 68).

Kazak feodallerinden sultan, bey, hatip, subay vb. çocuklarına, Neplyuev Kadet Binası (1825) ve Ombı Kadet Binası (1848) gibi okullarda önemli ayrıcalıklar tanınarak buralarda eğitim almaları sağlanmıştır. Illk Kazak Okulu 1841 yılında Bökey Han Döneminde açılmış olup daha sonraki okul ise 1850 yılında Orınbor' daki sınır komisyonunun yanında açılarak eğitim-öğretime başlamıştır.

Çarlık Rusya Halk Eğitim Bakanlığı, 1870 yılında kendisine tabi olan halklara eğitim konusunda özel bir kanun çıkarmıştır. Çıkarılan bu kanuna göre yabancı yerlerde ve sınır bölgelerinde yaşayan halka Ruslaştırma politikası misyonunda eğitim verilmiş ve bu eğitim sistemi yaygınlaştırılmıştır.

Moskova'da kurulan bu özel misyonerlik cemiyetinin temel prensiplerinde şu hususlar yer almıştır:

- Müslüman nüfuslu yerleri farklı bölgelere dağıtmak,

- Türk ve Müslümanların aralarını açmak, nifak tohumları ekmek, birbirlerine karşı kışkırtmak,

- Pantürkizm ve Panislamizm'e karşı mücadele etmek,

- Ruslara tabi olan tutsak halkları Ortodoksluk dinine geçirerek Hıristiyanlaştırmak,

- Halkı kendi tarihinden ve millî medeniyetinden uzaklaştırmak,

- Halkları Rus alfabesine geçirmek,

- Müslüman okullarını ve medreselerini kapatmak, bunların yerine Rus veya Rus-Kazak okullarını açmak ve daha sonra bu okulların tamamını saf Rus diline geçirmek, 
- Sömürgecilik siyasetine uygun olarak yabancı yerlerdeki ve sınır bölgelerindeki misyoner âlim ve öğretmenlerin sayısını çoğaltmak,

- Bütün toplumları Ruslaştırmaktır (Kurmanalina, Mukanova, Galimova ve illyasova, 2010: $69)$.

Kazak toplumunun eğitim çalışmaları, Kazakların ilk öğretmeni olarak kabul ettikleri Ibıray Altınsarin ismiyle sıkı sıkıya ilişkilidir. Ibıray Altınsarin'in Kazak bozkırında eğitim çalışmalarındaki katkısı bugünkü eğitim çalışmalarının temelini oluşturmaktadır. Onun eğitim çalışmaları, Kazak halkının yüzyıllarca maddî, manevî ve ruhanî sömürge siyasetine maruz kaldığı, baskı ve eziyetlerin yaşandığı bir zamana tesadüf etmiştir.

Ibıray Altınsarin (1841-1889): Rus dilinin Kazaklara öğretimi kursunun öncüsü ve bu kursun plan ve programlarının yazarıdır. Ibıray Altınsarin, Rus dili ile Kazak dilinin farklılıklarını tespit ederek açıklamalar yapmış ve eğitim-öğretim sürecinde görsel eğitim, konuşma, anlatım ve kitapla çalışma yöntemlerini her zaman desteklemiştir. I. Altınsarin, Rus dilini öğretmek için hazırlık sınıfları açmış, sözlü konuşma yöntemlerini kullanarak öğrencilere Rus edebiyatı ve dil bilgisi eğitimi vermiş ve Kazak dilinde az söylenilen kelimelerle ilgili önemli sözlük çalışmaları yapmıştır.

Altınsarin'in 1879 yılında eğitim materyali olarak hazırlamış olduğu “Kırgız Hrestomatiyası” yani Kırgız örnek metinlerinin yer aldığı bir de kitap yazmıştır. Bu kitap, Kazak dilindeki ilk eğitim kurallarının yer aldığı çalışma olup daha sonra sözlü edebiyat eserleri, bitki ve teknik isimler de bu eserin içerisine dâhil edilmiştir (Kurmanalina, Mukanova, Galimova ve Ilyasova, 2010: 271-272).

Ibıray Altınsarin'in katkılarına rağmen Rus etkisi, Kazak eğitim sistemindeki ağırlığını devam ettirmiş ve dönemin Kazak siyaset ve eğitimcilerin yerel ve siyasî güçleri bunu engellemede maalesef yeterince başarılı olamamıştır. Süreç içerisinde Rusya'nın eğitim sistemi içerisindeki misyonerlik faaliyetleri artarak devam etmiş ve bu durum Kazakistan'daki eğitim yasalarına da yansıyarak eğitimöğretim sisteminin yeni bir boyuta girmesine neden olmuştur.

19. yüzyılın sonlarına gelindiğinde Kazak okullarının nasıl olması gerektiği konusu iki farklı bakış açısı ile tartışımaya başlamışır. N. İ. İlminski, Kazak halkının eğitim seviyesinin alt düzeyde kalması gerektiğini ve Kazakların kendi öz benliğinden ve medeniyetinden uzaklaştırılarak Ruslaştırılmasını savunmuştur. Buna karşın Ibıray Altınsarin, Şokan Valihanov, Abay Kunanbayev gibi Kazak aydın ve eğitimcileri, gelişmiş Rus medeniyeti ve eğitiminin olumlu örneklerinin Kazak halkına uyarlanarak toplumun eğitim seviyesinin yükseltilmesi gerektiğini savunmuşlardır.

Eğitim-öğretimin Cedit hareketi diye adlandırılan akım, Ruslaştırma -sömürgecilik- siyasetine karşı Türkçe konuşan toplumların kendi kendini muhafaza etme yolundaki dayanıklı ve yılmaz mücadelesinden doğmuştur. Sömürgeciler, bu düşünceyi küçümsemiş ve Ceditçileri bilgisiz olarak nitelendirmişlerdir. Çarlık hükümeti, millet mekteplerindeki eski düzen dinî Arapça eğitim ile Arap harfleriyle yapılan yeni eğitim sisteminin mensuplarını birbirine karşı tahrik ederek millî şuurun 
uyanmasını engellemiştir. Bu durum neticesinde eski sistemi savunan Hadim akımının vekilleri, yeni sistemi savunan Cedit akımının vekillerini Allah'a şirk koşma iddiasıyla suçlamış ve bu konuyu onların üzerinden Çarlık hükümetine dilekçe yazılmasına kadar götürmüşlerdir. Cedit akımına karşı olanlardan biri de N. İ. İlminski'dir (Kurmanalina, Mukanova, Galimova ve Illyasova, 2010: 69-70).

Cedit akımı mensuplarının okul ve medreselerle ilgili düşünceleri şu şekilde sıralanabilir:

- Aynı biçim ve içerikte bir eğitim-öğretim müfredatı programı hazırlamak ve böylece Müslüman okullarının hepsini bir düzene koymak,

- Eğitim planına; aritmetik, coğrafya, fen bilimleri, tarih vb. dersleri ilave etmek ve çağdaş sistemin taleplerine uygun olarak öğrencilere eğitim vermek,

- Eğitim için gerekli olan tüm imkânları sağlamak,

- Cahil ve bağnaz mollaları -eğitimcileri- gerekli donanıma sahip olan mollalarla değiştirmek,

- Sesli okuma metoduna geçmek,

- Mektep ve medrese bitirenlere sınav yapmak,

- Öğrencilere gerekli dokümanları temin etmek,

- Askerlik görevini yerine getirmede kolaylıklar sağlamak,

- İslamî eğitim veren okulların gözetimini ve kontrolünü halkın seçtiği seçkin vatandaşlara vermek ve okulları, bölgenin resmî koruyucusu olan halka bağlamak,

- Okulların masraf ve giderlerine yardım etmek,

- Eğitim kurallarını belirlemek ve gerekli tüm imkânları sağlamak,

- Öğretmenlere düzenli olarak maaş ödenmesini sağlamak gibi konular üzerinedir.

Cedit hareketinin en önemli temsilcisi, tanınmış Türkolog Ahmet Baytursunov'dur. Ceditçiler, ilkokul yani temel eğitim konusuna ayrıca önem vermiş ve bununla ilgili birkaç eğitim kuralı da saptamışlardır. Cedit hareketi, ilkokul mezunlarının medreselerde ya da yüksek eğitim yerlerinde bilgilerini daha ileriye taşıma ve onların kendi istekleriyle uzmanlık alanı seçebilme imkânlarını da sağlamıştır. Bu durum, halkın bu okullara olan güvenini ve hevesini arttırmıştır (Kurmanalina, Mukanova, Galimova ve illyasova, 2010: 70).

Kazak pedagojisinin geliştiği dönem 3. dönemdir. Bu dönem Sovyet Rusya'nın kurulduğu 1917 yılından başlayıp Kazakistan'ın bağımsızlığını aldığı ve günümüze kadar uzandığı dönemi kapsamaktadır. Bu dönemde Rusya, kendisine tabi olan halkları elinde tutmanın yolunu eğitim-öğretim sahasında gerçekleştireceği politikalarda görmüş ve bu konu üzerine farklı yöntemler kullanarak amacına ulaşmaya çalışmıştır. Kazakları ve tüm Türk Dünyasını geçmişlerinden ve kültürlerinden uzaklaştırmak için farklı stratejiler izleyen Çarlık Rusya/Sovyet Rusya, bu amacına ulaşmak için de her yöntemi denemiştir. 
Yapılan tüm stratejilere rağmen bu dönemde Kazak halk pedagojisinde özel ve önemli değişiklikler de fark edilmiştir. Bu dönem içerisinde Ahmet Baytursunov, Magjan Jumabayev, Jüsipbek Aymavıtov gibi daha pek çok önemli ismi görmek, çalışmalarından bahsetmek ve Kazak millî eğitim sisteminin temellerini attıklarını söylemek mümkündür. Daha sonra Kazak millî pedagojisini geliştirmeye K. Jarıkbayev, T. Tajibayev, K. Birjanov vb. pek çok pedagog ve bilim adamının katkılar sağladıklarını görmekteyiz (Bayjanova, 2008: 20).

1917 Ekim devriminden sonra halkı bitkin düşüren seyahatler, iç savaşın kanlı durumu, zorluk ve felaketlerin etkisine rağmen ülkedeki okul sayısı bu dönemde bir hayli çoğalmıştır. O zamanlardaki eğitim siyasetindeki başlıca konularından biri de yeniden açılmakta olan köy okullarının öğretmen ihtiyacını karşılama ve gerekli imkânları sağlama durumu olmuştur. Bu yükümlülük üç şekilde yerine getirilmiştir.

Birinci yol; önceki dönem Çarlık Rusya'sının öğretmenlerini okullara çekmek; ikinci yol; eğitime hevesli ve bilgili gençleri kısa süreli kurslardan geçirmek; üçüncü yol ise; eğitim-öğretim yerlerini çoğaltarak öğretmen yetiştirmektir.

1920 yılında Kazak Eğitim Halk Komiserliği kurulmuştur. Onun Başkanlığına Ahmet Baytursunov getirilmiş ve 18 Şubat 1920 yılında Kazakistan'daki bütün konfederasyonlar bu halk komiserliğinin yapacağı organizasyona davet edilmiştir. Yapılan bu organizasyonda; öğrencileri koruyup gözetmek, eğitim sistemini bir düzen dâhilinde kurmak, meslekî ve teknik eğitim vermek, siyasî eğitim çalışmaları vb. gibi eğitim-öğretim çalışmalarıyla ilgili konular ele alınmıştır.

1922-1923 eğitim yıllarında "Akademik Merkez Millet Okulları" kişiye ait ders kitapları ile gerekli imkânları sağlama konularında işe yaramış ve Kazak dilinde 14 ders kitabı çıkarılmıştır. Bu kitapların içinde fizik, gramer, cebir, akıl sağlığı vb. alanlara ait kitaplar da bulunmaktadır. Bu ders kitaplarının yazımında Kazak aydınlarının önde gelen temsilcilerinden A. Baytursunov, M. Jumabayev, J. Aymavitov, M. Avezov, S. Asfendiyarov, T. Jomartbayev, K. Satbayev, A. Ermekov, T. Joldıbayev gibi önemli isimler görev almışlardır. Ülkede yüksek eğitim-öğretim mezunu personel hazırlamada ilk olarak Almatı şehrinde açılan Abay Kazak Pedagoji Enstitüsü büyük bir rol oynamıştır (Kurmanalina, Mukanova, Galimova ve illyasova, 2010: 71).

Ahmet Baytursunov (1873-1937): Kazak dili eğitim metotlarının temellerini atan önemli bir kişidir. "Oḳuw Ana Tilinde Jürgizilsin" adıyla kaleme almış olduğu çalışmasıyla eğitimin ana dilde yürütülmesini hedefleyen ve bu konuda ilk adımı atmış olan bir girişimcidir (Kurmanalina, Mukanova, Galimova ve ilyasova, 2010: 272).

Ahmet Baytursunov, Kazak halkını okumaya, bilime, eğitime, sanata, özgürlüğe ve eşitliğe davet etmiş ve bu çalışmaların tamamının ana dilinde yürütülmesinin gerekliliğini ilk olarak dile getirmiştir. Baytursunov, bir bilim adamı olarak dil özelliklerinin araştırılmasına da ayrıca önem vermiş ve konularla ilgili pek çok eser kaleme alarak çalışmalar yapmıştır. Ahmet Baytursunov, 1912 yılında ilk 
defa "Älippe" adında bir alfabe kitabı yazmıştır. Bu kitap, Kazak halkına okuma-yazma öğretmenin temel kurallarını içeren bir başucu kitabı olmuştur. Bu eğitim kitabı Kazaklara hem okuma-yazma öğretmiş hem de Kazak halkının millî dünya görüşüne geçme çalışmalarına bir amaç teşkil etmiştir. 1926 yılında "Älippe" (Alfabe) adlı eserin ayrıntılı bir şekilde kalitesi arttırılmıs ve yeni bir baskısı yapılmıştır (Bayjanova, 2008: 20).

Önemli bir metot uzmanı olan Ahmet Baytursunov, öğrencilere kural ezberletmenin faydasız olduğunu kanıtlayarak; öğretmenlere eğitim-öğretimde anlatma, yorumlama, analiz etme ve neticelendirme yöntemlerinin kullanılmasını önermiştir. A. Baytursunov, derslerde; duygulanmahissetme, yorumlama, çözümleme, şekillendirme ve sonuç çıkarma yöntemlerini kullanmanın ne kadar elzem olduğunu da "Ḳay Ädis Jaḳsı" (1928) “Hangi Yöntem İyi” adlı makalesinde açıkça ifade etmiştir.

Eğitim-öğretim çalışmaları için halkın ana dili olan Kazak Türkçesindeki okuma-yazma kurallarının bilinmesi gerekliliğini savunan Ahmet Baytursunov, bu gibi temel meselelere özel bir önem vermiş; millî imlâyı ve dil bilgisini eğitim temelinde yeniden oluşturarak onu gün yüzüne çıkarmada öncü olmuştur. Baytursunov, halkı cahillikten ve karanlıktan kurtarmak için bu eğitimin gerekli olduğunu kanıtlamıştır. A. Baytursunov, 1913 yılında "Ḳazakş̧a Oḳuw Jayınan” (Kazakça Eğitim Durumu) adlı bir başka makalesinde de öğretmenlik ilminin önemine dikkat çekerek çocuğa ders verecek ve ona bir şeyler öğretecek olan kişinin, öğrencinin gönül sarayını çok iyi bilmesi gerektiğini de söylemiştir (Kurmanalina, Mukanova, Galimova ve ilyasova, 2010: 272).

Kazakistan eğitim sisteminin gelişmesi ve çağdaş eğitim öğretim yöntemlerinin ihdas edilmesi konusunda çalışmalar yapan diğer eğitimciler şunlardır:

Jüsipbek Aymavıtov (1890-1931): "Terbiyege Jetekşi” (Eğitim-Öğretim Klavuzu, 1924) adlı eserinde öğrenciye eğitim-öğretim vermenin kurallarını ve kanunlarını anlatmıştır. Eğitim-öğretimin en doğru sistemi olarak pedagojinin öğretim bilgisi içerisindeki didaktiğin gerekliliğini savunan Jüsipbek Aymavıtov, bu konuda Kazak dilinde ilk ilmî çalışmayı ve açıklamayı yapan kişi olmuştur. J. Aymavıtov; öğrencilere doğduğu yerin millî kimliği ile örf adetlerini öğretmeyi teklif etmiş ve öğrencilerin kelime hazinesinin zenginleştirilmesine özellikle dikkat çekmiştir (Kurmanalina, Mukanova, Galimova ve Illyasova, 2010: 272-273).

Halkın etnopsikolojik özelliklerini de araştıran Jüsipbek Aymavıtov, bu alanla ilgili ilk çalışma olan "Psihologiya" adlı eseri yazmıştır. J. Aymavıtov; öğrencinin aklını, duygusunu, iradeli olmasını ve karakterini eğitmenin gerekliliğini yaptığı tüm çalışmalarında açıkça söylemiştir (Bayjanova, 2008: 20).

Magjan Jumabayev (1893-1938): Bu dönemde Kazak dili üzerine çalışmalar yapan bir başka Kazak aydını da Magjan Jumabayev'dir. Magjan Jumabayev'in yazdığı "Pedagogika" adlı kitap; Kazak halkının millî özelliklerine uygun olarak yazılan ilk pedagojik eserdir. Bu çalışmada, pedagoji dersinin anlamı ve eğitimin insan hayatındaki öneminden bahsedilmektedir (Bayjanova, 2008: 20). 
Jumabaev; eğitim-öğretimle ilgili öğretmen davranışlarının, materyallerin, etkinliklerin ve araçgereçlerin temel özelliklerini şöyle sıralamıştır:

- Öğretmenin anlaşıılır ve yüksek sesle konuşması,

- Kitapta yer alan resimlerin açıklı̆̆ı,

- İzlenim ve tesirin güçlülüğü,

- Eşyayı ve varlığı doğrudan gösterme,

- Eşyanın resmini yaptırma/çizdirme,

- Bir nesneyi çamurdan yaptırma,

- Öğrencinin dikkatini dağıtan unsurlara dikkat etmedir (Kurmanalina, Mukanova, Galimova ve ilyasova, 2010: 272-273).

M. Jumabayev, yukarıdaki hususları dikkate alarak eğitim-öğretimde başarıyı daha da arttırmak için; dersleri çeşitlendirmeyi, intiba ve izlenimi yenilemeyi, okumaya yeni başlayan öğrencileri 5-10 dakika okutmayı, yeni öğrenilen bilgilerle eski bilgileri ilişkilendirmeyi, yakından uzağa, bilinenden bilinmeyene yöntemiyle öğretmeyi teklif etmiştir.

$\mathrm{Bu}$ önemli gelişmelere rağmen Kazakistan'ın Sovyet Rusya döneminde maruz kaldığı değişimler, baskılar ve asimilasyonlar devam etmiş, yaşanan tüm bu baskılar ve asimilasyonlar maalesef Kazakların ana dillerinde ve millî eğitim sistemlerinde de etkili olmuştur. Yukarıda söylenilen hususları sistemli bir şekilde sürdürmeye devam eden Sovyet Rusya, eğitim temelinde Kazakistan'daki tüm millî unsurları bünyesinde barındıran Kazak Türkçesini de unutturmak istemiş, eğitimde ve hayatın tüm safhalarında Rusçayı ön planda tutmayı bir devlet politikası haline getirmiştir.

Bu dönem içerisinde;

- Bilim dili olarak Rusça kabul edilmiş,

- Kazak dili dâhil yapılan tüm bilimsel çalışmalar Rusça yapılmış/yazıımış,

- Rus dili ve edebiyatı bölümlerindeki kadrolar arttırılmış,

- Rusça öğrenimiyle ilgili kitaplar basılmış,

- Eğitim-öğretimde yeni ders kitapları hazırlanmış,

- Pek çok öğrenci pratik için Rusya'ya gönderilmiş,

- Her alanda Rusça ön plana alınmış, kısacası insanları Sovyetleştirme amaçlanmıştır (Boranbayeva, 2004: 26).

Sovyet Rusya, bir yandan coğrafyadaki Rus varlığını ve Rusçayı etkinleştirirken diğer yandan da Kazakistan'da kullanılan alfabeler üzerinde tam üç kez değişiklik yapmıştır. Kazakistan'da 1929 yılına kadar Arap harfleri kullanılmış olup 1929'dan 1940 yılına kadar Latin harfleri kullanılmış ve 1940'tan itibaren Kiril harfleri kullanılmaktadır (Kınacı, 2010: 1309). Üç kez alfabe değişikliği yapılmasıyla Kazakların eğitim ve medeniyeti büyük bir darbe almıştır. Eğitim-öğretim alanındaki bu gibi büyük 
saptırmalar millî kültür ve medeniyetin gelişmesini engellemiş ve bu unsurların geriye doğru gitmesine neden olmuştur. Şüphesiz burada amaçlanılan şey Kazakların geçmişleriyle yani benlikleriyle tüm bağlarını koparmaktır.

1940'lı yıllara gelindiğinde bu dönem içerisinde 2. Dünya savaşı yaşanmış ve Alman işgalcilerin hücumuna karşı çoğunluğunu erkeklerin oluşturduğu Kazak öğretmenler, vatanı düşmandan korumak için savaş alanlarına doğru yola çıkmışlardır. Öğrenciler ise tarım ve hayvan çiftliklerine yardım etmek ve savaş alanının ihtiyaçlarını karşılamak gibi görevler üstlenmişlerdir. Savaştan sonra, 1945-60 yıllarında, okullar ile oradaki öğrencilerin sayısı birden bire çoğalmaya başlamıştır. 1950-1960 yıllarında güçlü bir şekilde hayata geçirilen okulların sayısının artmasına rağmen Kazak okulları birer birer kapatılmaya başlamış ve kapatılan bu eğitim kurumları Rus veya Rus-Kazak okullarına dönüştürülmüştür. 1980-90 yıllarında orta öğretimin ülke düzeyinde bütün halkı kapsayacak şekilde yaygınlaştırılması çalışmaları başlatılmış ve bunun sonucu olarak okula başlama yaşı da altı olarak belirlenmiştir. Eğitim-öğretimde 1991 yılına kadar devam eden bu süreç, ilk başta Çarlık Rusya ve 1917 'den sonra da Sovyet etkisinin olduğu dönemleri kapsamıştır.

Kazakistan Cumhuriyeti, Sovyet Sosyalist Cumhuriyetler Birliğinin dağılmasından sonra 1991 yılında bağımsızlığını ilan etmiştir. Kazakistan'da 1991 yılına kadar “Kazak Sovyet Sosyalist Cumhuriyetinin Eğitim Bakanlığı" tarafından hazırlanan eğitim programları kullanılmıştır. Bu eğitimöğretim programlarının muhtevasını Sovyet Rusya’nın izlemiş olduğu politikalar belirlemiştir (Kaplankıran, 2016: 40). “Eğitim, bağımsızlığın ilk günlerinden itibaren Kazakistan toplumunun gelişiminde, ekonomik büyümesinde ve pazarın verimliliğinde Kazakistan Devlet Başkanı N. Nazarbayev tarafından öncelikli bir faktör olarak belirlenmiştir" (Tülbasiyeva, çev: İsina, 2007: 455). Kazakistan bağımsızlığını aldıktan sonra eğitimin esaslarını demokratik ve entegrasyon (bütünleşme) prensiplerine uygun olarak düzenlenmiş ve her çocuğun başkasından farklı özelliklerinin ve yeteneklerinin dikkate alındığı bir eğitim-öğretimi kurmak istemiştir. Bunun sonucu olarak millet mekteplerinin yeni programlarında önemli değişiklikler yapılmış ve eğitim-öğretim sistemi, özel eğitim alanlarında yeteneği olan çocukları kapsayacak şekilde yeniden düzenlenmiştir. Kazakistan Cumhuriyetinin eğitim alanındaki düzenlemeleri, hazırlanan yeni anayasada yerini almış ve yapılan yasal düzenlemeler ile ülkedeki diğer toplumsal değişikliklere paralel bir yapı kazanmıştır (Kurmanalina, Mukanova, Galimova ve ilyasova, 2010: 71-72) .

Uzun yıllar Çarlık Rusya ve Sovyet idaresi altında yaşayan Kazakistan'ın hem millî hem de idarî olarak istikrara kavuşması ve ülke genelinde etkili olması kolay olmamış, her konuda karşılaşılan bu sıkıntılar eğitim-öğretimde daha çok kendisini göstermiştir. "Sovyetler Birliği döneminde çok mükemmel olmasa da ücretsiz olarak halka sunulan sosyal hizmetler geçiş döneminde ciddi anlamda sekteye uğramıştır. Eğitim ve sağlık sektörleri geçiş dönemi sıkıntılarından en çok etkilenilen alanlar olmuştur" (Kuşçu, 2014: 24). 
Özellikle "bağımsızlık sonrası ilk yıllarda Sovyet sonrası topluma ve ekonomiye uygun müfredat geliştirmek, ders kitapları ve materyallerinin yenilenmesi gibi bir dizi sorun ortaya çıkmıştır" (Kuşçu, 2014: 26). Bu sorunlar “öğretmenlerin maaşlarının son derece düşük kalması ve öğretmenlerin modern müfredatlara uygun yetiştirilemeyişi de bağımsızlık sonrasında Kazakistan'ın karşı karşıya kaldığı önemli sorunlardır" (Kuşçu, 2014: 26). Bu problemlerin çözülmesi kolay olmamış, hatta uzunca bir süre bu uygulamalar Sovyet Rusya döneminden kalan usullerce devam etmiştir.

Kazakistan'ın yapacağı değişikliklerde dikkat etmesi gereken önemli bir husus da Rus nüfusun ülke genelindeki oranı olmuştur. "1989 nüfus sayımına göre ülkeye adını veren etnik grup Kazakların genel nüfusa oranları ancak \%39.7 idi. Ülkede azınlık olarak addedilemeyecek bir nüfus çoğunluğuna sahip Rusların oranı ise \%37.4 idi" (Kuşçu, 2014: 25). Bu nedenle yapılacak olan eğitim-öğretim sisteminin Kazakistan'daki tüm etnik unsurlara hitap etmesi ve ülkeyi bütünleştirici bir muhtevada olması en temel görevlerden biri olmuştur.

Tüm bu gelişmelerden sonra Kazakistan Cumhuriyetindeki eğitim-öğretim, Rus okullarında ve Kazak okullarında olmak üzere iki farklı şekilde yapılmaya başlamıştır. Ders kitapları, ders saatleri ve ders konularının tamamen farklııık gösterdiği bu kurumların bağlı oldukları bakanlık Kazakistan Eğitim ve Bilim Bakanlığı olup müfredat programlarını da bu bakanlığın bir alt birimi olan Ibıray Altınsarin Millî Bilimler Akademisi hazırlamaktadır. Rus okullarında sadece Ruslar eğitim görmeyip diğer milletlerden olan öğrenciler de isteğe bağlı olarak bu okullarda eğitimlerini alabilmektedir.

Kazakistan'da eğitim-öğretim alanındaki düzenlemeleri "Bilim Jäne Ġılım Ministrligi” olarak adlandırılan "Eğitim ve Bilim Bakanlı̆̆ı" yapmaktadır. "Eğitim alanını düzenleyen yasal düzenlemelerden ilki 1992 yılında kabul edilen Eğitim Kanunudur. Bu kanunun üçüncü maddesine göre eğitimin temel ilkeleri şunlardır: eğitim alma hakkında vatandaşların eşitliği, eğitim ve öğretim şekillerinde eğitim kurumlarının çeşitliliği, eğitimde süreklilik, eğitimin bilimsel ve seküler olması ile eğitim sisteminin idaresinde demokratik anlayış" olarak belirlenmiştir (Kuşçu, 2014: 27).

Kazakistan, bağımsızlıktan sonra eğitim-öğretim bilgisi dâhilindeki araştırma ve çalışmalarını arttırmış ve bu alanda yapılması gereken öncelikli hedefleri belirlemiştir. Bu çalışmalar bahsedilen dönemlerden itibaren Kazakistan Cumhuriyeti tarafından öncelikli yapılması gereken görev, yükümlülük ve hedefler listesinde yer almış ve hayata geçirilmeye başlanmıştır. Bu görev ve yükümlülükler genel hatlarıyla şu şekilde sıralanmaktadır:

- 1-11'inci sınıflar için tahsis edilen yeni ders kitaplarının yazılma çalışmalarını bitirmek ve bunları okullara göndermek,

- Eğitim seyrini ve sürecini büyütüp geliştirmek,

- Okulları bilgisayarlandırmayı 2002 yılına kadar bitirmek,

- Eğitim-öğretim seyrine yeni teknolojik materyalleri dâhil etmek, 
- Ülke genelinde gerekli olan tüm standartları yerine getirerek tamamlamak ve bunları adım adım okullarda uygulamak,

- Özel yetenekli öğrencileri ve eğitim-öğretim programlarını ilmî düzende belgelemek;

- Eğitim-öğretimi en iyi şekilde uygulamak,

- Eğitimin ilmî metot ve yöntemlerini yapmaktır (Kurmanalina, Mukanova, Galimova ve ilyasova, 2010: 272-273).

"Bir müfredat programının varlı̆ından söz edebilmek için öncelikle söz konusu devletin millî veya gayri millî bir maarif politikası olmalıdır" (Demir, 1997: 281). 1999 yılında kabul edilen eğitimöğretim hakkındaki kanun da bu kapsamda Kazakistan için ayrıca önem arz etmekte olup bu kanunla birlikte "eski SSCB Sovyet Partisi'ne hizmet eden eğitim sisteminin amaçlarının yerine, yeni çok seviyeli eğitim sisteminin amaçları yürürlüğe girmiştir" (Shuinshina, 2006: 33). Böylece okullardaki müfredat programları bu kanundan sonra yeni şeklini almaya başlamıştır.

Eğitim-öğretim reformlarını sürdüren Kazakistan, Sovyetler Birliğinin uyguladığı sosyalist politikanın yerine Avrupa'nın uygulamakta olduğu modern eğitim-öğretim sistemine geçmeye karar vermiş ve eğitim-öğretim müfredatında önemli değişiklikler yapmak için gerekli çalışmalara başlamıştır. “Kazakistan'da eğitimin geliştirilmesi 2005-2010 Devlet Programı, eğitim sisteminin artık geçerliliği olmayan bir metodoloji ve içeriğe dayandığını kabul etmiş ve müfredatta önemli değişiklikler yapılmasını başlıca hedef olarak ortaya koymuştur" (Kuş̧̧u, 2014: 28). Bütün bu gelişmelerin yanında "2007 yılında kabul edilen yeni Eğitim Kanununda da bu önceliklere vurgu yapılarak, Kazakistan eğitim sisteminin uluslararası standartlara yükseltilmesi gerekliliği vurgulanmıştır” (Kuş̧̧u, 2014: 28).

Kazakistan Cumhuriyetinde okullarda verilen genel eğitimin yanı sıra öğrencilerin sağlık şartlarına göre özel olarak da dersler verilmektedir. Bu özel durumlar için "Eğitim ve Bilim Bakanlığı Ibıray Altınsarin Bilim Akademisi" özel bir müfredat programı hazırlamış ve hazırlanan bu müfredat programında derslerin durumu, amaçları, içeriği ve işlenişi ayrıntılı olarak belirtilmiştir. Örneğin son şekliyle 2009 yılında güncellenerek hazırlanan “Özel Eğitim Verme Programı” engelli olup okula gidemeyecek durumdaki öğrenciler için hazırlanmıştır. Hazırlanan bu müfredat programına göre öğretmenler, hastane raporuyla okula gitmesinde engel teşkil eden öğrencilerin evlerine belirlenen saatler içerisinde gitmekte ve derslerini özel olarak öğrencilere anlatmaktadır. Öğretmenler, müfredatta belirlenen konu ve başlıklarda öğrenciye dersini anlatıp sınav yapmakta ve daha sonra başarılı olanlara okulları tarafından diplomaları verilmektedir (Kaplankıran, 2016: 42-43).

Kazakistan Cumhuriyetinde ülkedeki eğitim-öğretim işlerinden sorumlu olan bakanlık Eğitim ve Bilim Bakanlığıdır. Bu bakanlığa bağlı olarak çeşitli alt kuruluşlar yer almakta ve okullardaki müfredat programlarını bu alt kuruluşlardan biri olan Ibıray Altınsarin Millî Eğitim Akademisi hazırlamaktadır. "Ibıray Altınsarin Atındaġı Ulttık Bilim Berüw Akademiyası" tarafından hazırlanan müfredat 
programları, Kazak okullarında ve Rus okullarında yapılan eğitim-öğretim türüne göre farklılık göstermektedir.

Kazakistan Cumhuriyetinde eğitim sisteminin günümüzdeki yapısı "Genel Eğitim" ve "Meslekî Eğitim" olmak üzere ikiye ayrılmaktadır. Ortaöğretim zorunlu olup okul çağındaki bütün öğrencilere devletin yükümlülüğü altında ücretsiz verilmektedir. Kazakistan Cumhuriyetinin eğitim sistemi üç basamaktan oluşmaktadır:

- ilkokul 1-4. sınıfları,

- ortaokul 5-9. sınıfları,

- liseler 10-11. sınıfları, kolejler ise 10-11-12. sınıfları kapsamaktadır.

Kazakistan'da genel eğitim 3 basamaklıdır: İlkokul 1-4. sınıfları olup eğitim süresi 4 yıldır. Kazakistan Eğitim ve Bilim Bakanlığının tavsiye ettiği eğitime başlama yaşı 6 'dır. Ortaokuldaki eğitim 5.9. sınıfları kapsamaktadır. Ortaokuldan sonraki eğitim sistemi olan liseler ise genel orta eğitim olarak adlandırılmaktadır. Genel orta eğitim 10-11. sınıfları kapsamakta ve 2 yıl olarak belirlenmektedir. Ayrıca genel orta eğitimin yanında kolejler de eğitim-öğretim yapmakta ve buradaki eğitim dönemi 10-12. sınıfları içine alan 3 yıllık bir süreci kapsamaktadır.

Eğitim sürecinde öğrencilerin okullara başlama ve bitirme yaş grupları şöyledir:

- Ana okulu; 5-6

- Illkokul; 6-11

- Ortaokul; 11-15

- Lise; 15-17'dir.

Kazakistan'da meslekî eğitim-öğretim ise çeşitli şekillerde yapılmaktadır. Meslekî okullar; ilk ve orta meslekî eğitim kuruluşları, meslekî liseler ve kolejlerden oluşmaktadır. Bu okullara devam eden öğrenciler hem bir meslek öğrenmekte hem de eğitim-öğretimlerini tamamlamaktadırlar. Aynı zamanda öğrenciler "genel eğitim veren bir okula devam ederek orta öğretimini tamamlayabilir ya da 9 yıl genel öğretim veren bir okuldan sonra 2 yıl meslekî eğitim veren bir okula devam edebilir" bununla birlikte öğrenciler, meslekî eğitimin verildiği sanat okuluna gitmeyi de tercih edebilir (Shuinshina, 2006: 82).

Orta öğretim kurumlarının temel ilkesi; öğrencileri yetenek ve birikimlerine uygun olarak ayırmak ve bunlara uygun öğretim programlarına yerleştirmektir. Liseler; aynı zamanda öğrencilerin yeteneklerini fark ederek uzmanlıklarını öğrenmesine yardım etmekte ve buna uygun öğretim sağlayarak öğrenciyi daha ileriki seviyelere hazırlamaktadır. Kazakistan'da "ortaöğretim kurumlarını çeşitli kriterlere göre sınıflandırmak mümkündür. Tam gün eğitim yapanların dışında gece (akşam) eğitimi verenler de vardır. Ayrıca eğitim sisteminde sadece müzik veya teknik eğitim veren okullar, küçük çaptaki okul olmak üzere çeşitli ve çok programlı okullar da" bulunmaktadır (Shuinshina, 2006: 
71). Kazakistan'da liselerden mezun olacak olan öğrenciler için bir de bitirme sınavları yapılmaktadır. Bu sınavlar, ülke genelinde aynı günlerde yapılmakta ve başarıyla geçen öğrencilere okulları tarafından diplomaları verilmektedir.

Kazakistan Cumhuriyetinde genel ve meslekî okulları bitiren gençler üniversitelerde, enstitülerde, akademilerde, konservatuarlarda ve bu kurumlara denk olan eğitim-öğretim kurumlarında eğitimlerini almaktadırlar. Üniversitelerdeki eğitim-öğretim, bölümlerine göre 4 ile 7 yıl arasında farklıık göstermektedir.

Sovyetler Birliği zamanında üniversitelere öğrenci kabulü sözlü sınavla yapılmış olup bu durum üniversitelerin inisiyatifinde yer almıştır. Bu gelenek Kazakistan bağımsız olduktan sonra da 1999 yılına kadar devam etmiştir. Fakat "artan rüşvet ve yolsuzluk oranları bu uygulamanın sona erdirilmesini zorunlu kılmış" üniversiteye yerleşmek için Millî Bilim Testi Sınavına (Ulttık Birıñgay Testi) girmek zorunlu hâle getirilmiştir (Kuşçu, 2014: 29). Şimdi tüm öğrenciler bu bilim sınavına girerek aldıkları puanlar sonucunda bölümlerine yerleşmekte ve eğitimlerini sürdürmektedirler.

Kazakistan Cumhuriyetindeki eğitim sistemi çağın talepleri doğrultusunda sürekli olarak yenilenmekte ve böylece öğrencilere iyi bir öğretimin yapılması amaçlanmaktadır. Devlet; lisansüstü eğitim ve doktora programlarından mezun olmuş ve gerekli şartları yerine getirmiş vatandaşlarına doçentlik ve profesörlük unvanları vermekte ve kurumlardaki akademik personele duyulan ihtiyacı karşılamaktadır. Üniversitelerden sonra yapılan yüksek lisans 2 yıl, doktora ise 3 yıl sürmekte olup bu eğitim kurumlarında kredili sistem uygulanmaktadır. Günümüzde yüksek öğretim sistemini geliştirmek ve daha da ileriye götürmek için;

- "Bilgili meslek sahibi yetiştirme kalitesini yükseltmek,

- Lisans, yüksek lisans, doktora olmak üzere üç basamaklı üniversite öğretim sistemi oluşturmak (bu basamaklar akademik kredi biriktirmeyi temel almaktadır),

- Dünya öğretim alanına entegre olmak" hedeflenmektedir (Tülbasiyeva, çev: İsina, 2007: 458).

Kazakistan Cumhuriyetinin eğitim sistemi ve altyapısl; okul, kolej, lise ve diğer eğitim kurumlarını kapsayacak şekilde planlanmıştır. Zorunlu eğitim-öğretim 11 yıldır ancak Kazakistan Eğitim ve Bilim Bakanlığı zorunlu eğitimin 12 yıla çıkarılması için çalışmalar yürütmektedir.

Bir yılda dokuz ay eğitim-öğretim yapılan Kazakistan'da dönemler dörde bölünmekte ve dört doksan diye adlandırılmaktadır. Eylül ayının 1'inde başlayan eğitim-öğretimin her döneminde öğrencilere karneleri verilmekte ve o hafta okullar tatil olmaktadır. Öğrenciler cumartesi de dâhil olmak üzere 6 gün okula gitmektedir. Eğitim-öğretimin 5 güne indirilmesi için Kazakistan Eğitim ve Bilim Bakanlığı tarafından çalışmalar yürütülmektedir.

Eğitim-öğretimde tatil günleri; birinci dönem olarak adlandırılan kasım ayında 1 hafta, ikinci dönem olarak adlandırılan aralık ayında 10 gün, üçüncü dönem olarak adlandııılan mart ayında 12 gün 
ve son olarak yaz tatilinde üç ay olarak uygulanmaktadır. Okullar 25 Mayıs'ta tatil edilmekte olup yaz tatili haziran, temmuz ve ağustos aylarını kapsamaktadır.

Kazakistan'da günümüzde Kiril alfabesi kullanılmakta olup Devlet Başkanı Nursultan Nazarbayev, 2025 yılına doğru Latin alfabesine geçiş için alt yapı çalışmalarının oluşturulmasını istemiş̧ir (Urakova, 2014: 102). “Özellikle asrımızda insan unsuru, kültür ve bilgi ülkelerin en önemli güçlerini oluşturmaktadır. Kazakistan ve diğer Türk cumhuriyetlerinin Türkiye gibi Latin alfabesine geçmesi, düşünce ve uygulamalarda Türk dünyasının her yönden güçlenmesine ve yükselmesine yol açacaktır" (Kutalmış, 2004: 13).

"Müfredat programları bir devletin siyasî, millî ve sosyolojik gayelerinin maarifle ilgili hususlarını tespit ederek bunları okullarda gerçekleştirme faaliyetinin plânlanmasıdır" (Demir, 1997: 281). Bu programlar, eğitimi yapılacak olan derslerin bir sistem, düzen ve metot dâhilinde ele alınarak daha iyi öğretilmesini amaçlamakta ve eğitim-öğretimde düzeni, gidişatı ve planlı olmayı sağlamaktadır. Bu amaçlarla şuan Kazakistan'da 3 Nisan 2013 yılında Eğitim ve Bilim Bakanlığı Ibıray Altınsarin Millî Eğitim Akademisi tarafından hazırlanan müfredat programı kullanılmakta olup bu müfredat programı 10 Nisan 2013 tarihinde Kazakistan Adalet Bakanlığı tarafından onaylanarak kabul edilmiştir. Bu müfredat programına 18 Haziran 2015 yılında Eğitim ve Bilim Bakanlığının teklifiyle bazı değişiklikler ve ilaveler yapılmıştır. Yapılan bu değişikliler de 14 Temmuz 2015 tarihinde Kazakistan Adalet Bakanlığı tarafından onaylanmıştır.

Kazakistan Cumhuriyetinin tüm okullarında kullanılan 2013 Müfredat Programında, anaokulundan 11. sınıfa kadar tüm derslerin ders saatleri, materyalleri, konu dağılımları, örnekleri ve açıklamaları ayrıntılı olarak verilmektedir. Buna rağmen programlar devamlı güncellenmekte ve günden güne daha sistemli, daha çağdaş ve bir önceki programa göre daha kapsayıcı bir nitelik kazanmaktadır.

\section{Değerlendirme ve Sonuç}

Kazakistan, bağımsızlığını aldıktan sonra pek çok alanda olduğu gibi eğitim alanında da önemli çalışmalar yapmış, bu alandaki çalışmaları desteklemiş ve eğitim merkezinde ülkenin her yönde başarııını arttıracak önemli adımlar atmıştır.

Kazakistan Cumhuriyetinde eğitim sisteminin kurulması eğitim hakkında (Bilim Turalı) kanunu esasında olup bu eğitim sisteminin yapısı "Genel Eğitim" ve "Meslekî Eğitim" olmak üzere ikiye ayrılmaktadır.

Kazakistan Cumhuriyetindeki eğitim-öğretim, Rus okullarında ve Kazak okullarında olmak üzere iki farklı şekilde yapılmaktadır. Ders kitapları, ders saatleri ve ders konularının tamamen farklıık gösterdiği bu kurumların bağlı oldukları ilgili bakanlık Kazakistan Eğitim ve Bilim bakanlığı olup müfredat programlarını da bu bakanlığın bir alt birimi olan Ibıray Altınsarin Milli Bilimler Akademisi 
hazırlamaktadır. Rus okullarında sadece Ruslar eğitim görmeyip Kazaklar da dâhil diğer milletlerden tüm öğrenciler isteğe bağlı olarak eğitimlerini alabilmektedir.

Kazakistan'daki zorunlu eğitim-öğretim 11 yıl olup Eğitim ve Bilim Bakanlığı 12 yıla çıkarılması için çalışmalar yürütmektedir. Kazakistan Cumhuriyeti, hazırlanan yeni müfredat programlarında "Sovyet Partisine" hizmet eden eğitim-öğretim sistemi yerine uluslararası standartlardaki eğitimöğretimi hedeflemekte ve bu amaçla çalışmalarını arttırmaktadır.

Bir yılda dokuz ay eğitim-öğretimin yapıldığı Kazakistan'da dönemler dörde bölünmekte ve dört doksan diye adlandırılmaktadır. Eylül ayının 1'inde başlayan eğitim-öğretimin her döneminde öğrencilere karneleri verilmekte ve o hafta okullar tatil olmaktadır.

Kazakistan'da 1940 yılından itibaren Kiril alfabesi kullanılmakta olup Latin alfabesine geçilmesi için çalışmalar sürmektedir.

Kazakistan'daki eğitim sistemi Türkiye'deki eğitim sistemiyle büyük benzerlikler taşımakta ve çıkarılan kanunlarla yeni teknik ve yöntemler geliştirilmektedir. Böylece Kazakistan'daki eğitim çalışmaları daha sistemli, daha düzenli ve her geçen güne göre daha kapsayıcı bir nitelik kazanmaktadır. Aynı zamanda eğitim çalışmalarının millî ve kültürel unsurlar dâhilinde oluşturulması Kazakistan'ın bu alanda kat ettiği mesafeyi de gözler önüne sermektedir.

\section{Öneriler}

1) Kazakistan Cumhuriyetindeki bilimsel araştırmalarda pedagojik alan da dikkate alınmalı ve bu alandaki çalışmalara daha fazla yer verilmelidir.

2) Kazakistan'daki eğitim-öğretim sistemi detaylıca incelenmeli ve ilgili çalışmalardan yararlanılmalıdır.

3) Kazakistan'ın Latin harflerine geçmesi konusunda gerekli alt yapı çalışmalarına yardımcı olunmalıdır.

4) Türk Dünyasındaki ilgili Bakanlıklar ortak bir müfredat programı geliştirmeli ve çalışmalarını bu doğrultuda yeniden gözden geçirmelidirler.

5) Tüm bu önerileri hızlı bir şekilde hayata geçirmek ve dilde, fikirde, işte birlik mefkûresini daha da geliştirmek için gerek Kazakistan gerek Türkiye, eğitim-öğretim alanındaki çalışmalarını daha da arttırmalıdır.

\section{Kaynaklar}

Bayjanova, Z. (2008). Jalpı pedagogika, Almatı: Taymas Baspa Üyi.

Boranbayeva, S. G. (2004). Sscb dönemi ve bağımsızlık sonrası Kazakistan Cumhuriyetinde Kazak dilinin genel durumu. Ankara Üniversitesi Modern Türklük Dergisi Araştırmaları, Cilt 1, S. 1, 20-41. 
Demir, C. (1997). Atatürk döneminde bir ve tam devreli liselerde (ortaokul ve liselerde) Türk dili ve edebiyatı eğitimi ve öğretimi. Yayımlanmamış Doktora Tezi, Ankara: Gazi Üniversitesi Sosyal Bilimler Enstitüsü.

Demir, S. B., Doğan, S. ve Pınar, M. A. (2013). 4+4+4 Yeni eğitim sistemi'nin yansımaları: beşinci sınıflardaki eğitimöğretim sürecinin branş öğretmenlerinin görüşleri doğrultusunda değerlendirilmesi. Turkish Studies, Volume 8/9, s. 1081-1098.

Ergün, M. (2008). Cumhuriyet dönemi eğitim tarihi. Türkiye Araştırmaları Literatür Dergisi, 6/12, S.321-348.

Kaplankıran, İ. (2016). Kazakistan'da 7. sınıf ders kitabı üzerinden ana dili öğretimi üzerine bir inceleme. Yayımlanmamış Yüksek Lisans Tezi, Afyonkarahisar: Afyon Kocatepe Üniversitesi Sosyal Bilimler Enstitüsü.

Kazakstan Respublikasındagı bilim turalı zannama. (2014). Almatı: Yurist Baspası.

Kınacı, C. (2010). Sovyetlerden günümüze Kazakistan'da Kazak dilinde eğitim politikaları. Turkish Studies, 5/4, s. 1304-1319.

Koç, K., Bayniyazov, A. ve Başkapan, V. (2003). Kazak Türkçesi Türkiye Türkçesi sözlüğü, Ankara: Akçağ Yayınları. Kurmanalina, Ş., Mukanova, B., Galimova, A. ve İlyasova, R. (2010). Pedagokiga, Astana: Foliyant Baspası.

Kuşçu, I. (2014). Bağımsız Kazakistan'da eğitim ve sağlık: sorunlar, reform süreci, uluslararası aktörlerin rolü. Orta Asya ve Kafkasya Araştırmaları Dergisi (OAKA), Cilt: 9, Sayı: 18, s. 23-46.

Kutalmış, M. (2004). Tarihte ve günümüzde Kazakistanın alfabe meselesi. Bilig, Sayı 31, s. 1-21.

Shuinshina, N. (2006). Türkiye'de Kazakistan eğitim sistemlerinin örgütsel yapılarının karşılaştırılması (Merkezi ve taşra teşkilatı açısından). Yayımlanmamış Yüksek Lisans Tezi, Ankara: Gazi Üniversitesi Eğitim Bilimleri Enstitüsü.

Tülbasiyeva, L. (2007). Kazakistan'ın eğitim sistemi ve yeni gelişmeler, Çev: Dr. Almagül İsina, İslam Ülkeleri Kongresi, 24-27 Ekim, İstanbul, s. 455-460.

Urakova, L. (2014). Geçmişten günümüze Kazakistan'daki dille ilgili yasa koyuculuğa genel bir bakış. Türkbilig, Sayı 28, s. 97-104.

Yazıcıoğlu, ì. (2010). Örgütlerde iş tatmini ve işgören performansı ilişkisi: Türkiye ve Kazakistan karşılaştırması. Bilig, Sayı 55, 243-264. 